\title{
Variation in white spruce needle respiration across the species range
}

1 Kevin L. Griffin 1,2,3*, ORCID 0000-0003-4124-3757, Zoe M. Griffin 4, 0000-0003-4821-9557, Stephanie C.

2 Schmiege ${ }^{2,5}$, ORCID 0000-0001-9054-5538, Sarah G. Bruner ${ }^{2,000-0001-7103-9664}$, Natalie T. Boelman ${ }^{3}$,

3 ORCID 0000-0003-3716-2372, Lee A. Vierling 6, ORCID 0000-0001-5344-1983, Jan U. H. Eitel 6,7, ORCID 0000-0003-

$4 \quad 1903-3833$

5

$6 \quad{ }^{1}$ Department of Earth and Environmental Sciences, Columbia University, Palisades, NY 10964,

7 USA.

$8{ }^{2}$ Department of Ecology, Evolution and Environmental Biology, Columbia University, New

9 York, NY 10027, USA

$10{ }^{3}$ Lamont-Doherty Earth Observatory, Columbia University, Palisades, NY 10964, USA

$11{ }^{4}$ Department of Geography \& Environmental Sustainability, SUNY Oneonta, Oneonta, NY

1213820 , USA

$13 \quad{ }^{5}$ New York Botanical Garden, Bronx, NY 10458, USA

$14{ }^{6}$ Department of Natural Resources and Society, College of Natural Resources, University of

15 Idaho, Moscow, ID 83843, USA

$16{ }^{7}$ McCall Outdoor Science School, College of Natural Resources, University of Idaho, McCall, ID

1783638, USA

18 * Correspondence:

19 Kevin L. Griffin

20 griff@LDEO.columbia.edu

21 Orcid ID 0000-0003-4124-3757 


\section{Abstract}

23 White spruce (Picea glauca) spans a massive range from arctic treeline to temperate forests. Yet

24 the variability in respiratory physiology and the implications for tree carbon balance at the

25 extremes of this distribution remain enigmasWorking at Arctic and Temperate sites more than

$265000 \mathrm{~km}$ apart, we measured the short-term temperature response of dark respiration (R/T) at

27 upper and lower canopy positions. R/T curves were fit to a polynomial model and model

28 parameters $(a, b$, and $c$ ) were compared between locations, canopy positions, or with published

29 data. Respiration measured at $25^{\circ} \mathrm{C}\left(R_{25}\right)$ was $68 \%$ lower at the southern location than the

30 northern location, resulting in a significantly lower $a$ parameter of the $\mathrm{R} / \mathrm{T}$ response in temperate

31 trees Only at the southern location did upper canopy leaves have a steeper temperature response

32 than lower canopy leaves, likely reflecting steeper canopy gradients in light. No differences were

33 manifest in the maximum temperature of respiration. At the northern range limit, respiration

34 appears extreme. This high carbon cost likely contributes to the current location of northern

35 treeline. We find that respiration will increase with end-of-the-century warming and will likely

36 continue to constrain the future range limits of this important boreal species.

\section{Keywords: Picea glauca, Canopy gradients, Carbon balance, Dark Respiration, Arctic}

\section{Treeline}

39 Summary Statement: White spruce (Picea glauca) needle respiration at the northern limit of

40 the species range is three times higher than at the southern range limit. This extreme carbon cost likely challenges tree survival and contributes to the location of the northern treeline. 


\section{Introduction}

44 The distribution range of a species delineates the geographical location where historical, physiological and biotic filters combine to result in its successful growth and reproduction (Lambers \& Oliveira, 2019). The niche-breadth hypothesis explains species distributions based on envelopes of environmental conditions tolerated (Lowry \& Lester, 2006), yet to this day there is still no universally accepted "cause" delineating a species' range despite a long history of debate (see Casazza et al., 2005; Kruckeberg \& Rabinowitz, 1985; Kunin \& Gaston, 1993; Lavergne et al., 2004; Stebbins, 1942; Watson, 1833). Clearly many other evolutionary and ecological factors influence species range distributions, including genetic diversity, phenotypic plasticity, mating systems and metapopulation dynamics (reviewed in Brown et al., 1996; Gaston, 1996; Lowry \& Lester, 2006). Still the role of the growth environment is undeniable and links a species' distribution to its physiological performance. Using a physiological approach to understand the complex relationships between climate and the distribution of species can be preferable to simple climate envelope models because the former is capable of predicting species distributions under a variety of possible environmental conditions (Hijmans \& Graham, 2006; Malanson et al., 1992; Prentice et al., 1992).

Physiological processes such as photosynthesis, respiration and growth all respond strongly to local environmental conditions. Together these processes constrain plant carbon balance and thus contribute to a species distribution range (part of the physiological filter of Lambers \& Oliveira, 2019). Here we concentrate on leaf respiration. This flux is less well studied than photosynthesis, provides a crucial link between photosynthesis (carbon gain) and growth (carbon sequestration) and has been hypothesized to control the range distribution of individual species (Criddle et al., 2003). Furthermore, respiration is highly temperature sensitive, making it an important determinant of ecosystem productivity (Valentini et al., 2000). GlobResp, a global database of plant respiratory characteristics, identifies latitudinal gradients in leaf respiration measured at a common temperature that increase with absolute latitude. These findings suggest that species with a large range should exhibit variable rates of respiration across their distribution, although this hypothesis has not been explicitly tested (Atkin et al., 2015). Furthermore, Patterson et al. (2018) quantified respiratory rates and responses to temperature in 16 tree species growing in a common location, grouping them by their relative location within their individual species distributions. The results show that northern ranged species growing near their southern range limit had $71 \%$ higher respiration rates (measured at $20^{\circ} \mathrm{C}$ ) than southern ranged species growing near the northern edge of their range limits. Quantifying respiratory characteristics of individuals growing near the margins of their species range distributions can thus elucidate physiological 77 controls of the current distribution.

78 Recently we reported that white spruce (Picea glauca (Moench) Voss) growing at the arctic treeline (which marks the transition between the boreal forest and treeless tundra occurring in the Forest Tundra Ecotone (FTE)) exhibit exceptionally high respiratory costs (Griffin et al., 2021). This species has a transcontinental range in North America and while it is one of the most common tree species defining the FTE (Sutton, 1969), it also has a remarkably large species distribution stretching from the west coast of Alaska to the east coast of Canada and New

84 England (US Geological Survey, 1999) (Figure 1). One of the hardiest coniferous species, white spruce has a suite of structural and functional traits that are adapted to cold temperatures and short growing seasons. However, ambient environmental conditions at the southern edge of its 
range distribution can be markedly different from those at treeline. Perhaps surprising given its large geographical range, several studies show that white spruce has limited physiological plasticity (Benomar et al., 2018; Man \& Lieffers, 1997; McNown \& Sullivan, 2013; Prud'Homme et al., 2018; Stinziano \& Way, 2017; Weger \& Guy, 1991). However, McNown \& Sullivan (2013) working across a gradient that included terrace, forest and treeline sites, demonstrated that the physiological capacity of white spruce can vary due to other site factors such as soil properties and nutrition, even when climatic variables like temperature are constant. To our knowledge no studies have compared the respiratory characteristics of this species at the opposite ends of its distribution where climate and light conditions differ dramatically.

The goal of this research was to gain a better understanding of how respiration varies across the white spruce species range, and to explore the potential impact of respiration on leaf carbon balance, tree growth and survival. This is done by taking advantage of our recent detailed assessment of white spruce respiratory physiology at the Alaskan FTE, and then using identical techniques, we compare this to the physiological function of spruce growing more than $5000 \mathrm{~km}$ away at the opposite end of the species distribution. We test four research hypotheses. First, that leaf respiration measured at $25^{\circ} \mathrm{C}\left(R_{25}\right)$ in will decrease with latitude (Atkin et al., 2015). We extend this to examine the overall temperature response of respiration. Second, while our previous study did not find canopy position differences in respiration at the FTE (Griffin et al., 2021), we hypothesize that at our southern site upper canopy leaves will have higher respiration rates and be less responsive to temperature than lower canopy leaves. Light acclimation has been shown to affect respiration rates in white spruce dramatically (Awada \& Redmann, 2000) and there are intra-canopy gradients in light absorption in the dense canopy at Black Rock Forest (Schmiege et al., pers com). Furthermore, the top of the canopy is often the most physiologically active portion of a tree crown and has been shown to affect both average respiration rates and the response of respiration to temperature of leaves at various canopy depths (Griffin et al., 2001, 2002). Third we hypothesize that southern but not northern spruce respiration will be similar to the average for the Needle leaved Evergreen (NLEv) plant functional type to which they belong. To quantify white spruce respiratory temperature response and make these comparisons, we use the global polynomial model of Heskel et al. (2016). Fourth, we hypothesize that trees from the southern edge of the species range will have a higher temperature tolerance than trees from the northern edge of the distribution. To test this, we quantify $T_{\max }$, the leaf temperature at which the maximum rate of respiration is reached, from the respiratory temperature response to curves. Finally, we examine the general relationships between respiratory traits and leaf traits. The two specific locations of this study are Black Rock Forest, located in the Hudson highlands of NY, and the FTE in north central AK, USA (Figure 1. Referred to as the "southern location" and "northern location" respectively). Our southern site is the same location as the species range study described earlier (Patterson et al., 2018) and represents an extreme southerly location for white spruce. By quantifying these variables at the extremes of the species distribution, we characterize the mechanistic contribution of respiration to the current and potential future distribution of white spruce.

\section{Materials and Methods}

Site Descriptions and Leaf Material: This research was conducted at two sites representing the opposite ends of the species range, Black Rock Forest (BRF), New York, USA (41 ${ }^{\circ} 24^{\prime} 03.91^{\prime \prime} \mathrm{N}$ latitude, $74^{\circ} 01^{\prime} 28.49^{\prime}$ ' W longitude - southern location) and the Forest Tundra Ecotone (FTE), 
AK USA (67 $59^{\prime} 40.92^{\prime \prime} \mathrm{N}$ latitude, $149^{\circ} 45^{\prime} 15.84^{\prime \prime} \mathrm{W}$ longitude - northern location). The sites are more fully described elsewhere (Eitel et al., 2019, Patterson et al 2018). Briefly, the average annual precipitation at the southern location is $1285 \mathrm{~mm}$ and mean annual temperature is $10.9^{\circ} \mathrm{C}$ (Arguez et al., 2010). The northern location is spruce dominated evergreen forest (Eitel et al., 2019), while the southern location is a northern temperate deciduous forest that is oak dominated (Patterson et al., 2018; Schuster et al., 2008). The southern location is to the south of the natural species range distribution presented by Little (1999). White spruce was probably introduced into BRF as nursery stock for forestry trials in the early 1930's but has since expanded naturally. The trees used for this study were naturally seeded on the forest edge along Continental Road, a dirt trail established during the Revolutionary War to facilitate troop travel between West Point and the encampment of the Continental army in New Windsor. While the trail represents a break in the forest canopy it gets limited use and has only a minor impact on the canopy-dominant study trees located at least $15 \mathrm{~m}$ from the road.

Leaves used for the respiration measurements from the southern site were from south facing branches collected in late June and early July of 2018 from six study trees and came from the upper ( $1 \mathrm{~m}$ below the apical meristem) and lower (1.37 $\mathrm{m}$ from the ground) canopy positions. As in our FTE study (Griffin et al., 2021), the terminal portions of several branches were cut with sharp pruners and the removed portion of the stem was immediately wrapped with wet paper towels, sealed in a plastic bag with ample air and placed in cooler where they could be kept dark and transported to the lab. The top of the canopy was accessed with an articulating boom lift. Once returned to the lab, the stem pieces were recut underwater and then placed in a beaker containing enough water to submerge the cut end until analyzed, typically within 8 (but no more than 24) hours. Leaves from the northern site are a subset of data used by Griffin et al., (2021) and thus are described fully there. The motivation of that study was to assess the effect of tree size (saplings vs. trees) and test current hypotheses about the location of treeline. No saplings were sampled at the southern location and the effect of tree size/development is not specifically of interest here. Thus, the Griffin et al. (2021) dataset was trimmed to exclude all saplings (stems $<10 \mathrm{~cm} \mathrm{DBH})$, leaving 18 individual trees $(\geq 10 \mathrm{~cm} \mathrm{DBH})$ and re-analyzed for the present study. No part of the analysis presented here was included in the earlier publication.

Respiration Temperature Response Curves: The techniques employed here were identical to those used in our treeline study in order to facilitate this direct comparison. Thus, methods are described more fully in Griffin et al., (2021). Briefly, $\mathrm{CO}_{2}$ exchange rates were measured on needles that were carefully removed from the stems, weighed to determine the initial fresh mass (g) and placed in a fine nylon mesh bag. The mesh bag containing the leaves was placed inside a custom-made cuvette (Patterson et al. 2018, Li et al. 2019, Schmiege et al. 2021) with computer controlled thermoelectrical cooling (CP-121 Thermoelectric Peltier Cooling Unit, TE Technology, Traverse City, MI USA). The custom cuvette was interfaced with a portable photosynthesis system (Li-6400XT, LiCor Lincoln, Nebraska USA) which recorded all gas exchange and environmental parameters every 20 seconds.

After equilibrating the system to $5^{\circ} \mathrm{C}$, the mesh bag holding the leaves was sealed inside. Once stability was reached the instrument was zeroed and the response curve was measured as described in Heskel et al. (2016), O'Sullivan et al. (2013), and Schmiege et al. (2021). During measurements the flow rate through the cuvette was set to $500 \mathrm{ml} \mathrm{min}^{-1}$ and the $\mathrm{CO}_{2}$ 
concentration to $400 \mathrm{ppm}$. The air was dried using a Li-6400XT desiccant column and then transpiration was allowed to humidify the cuvette. During the measurement the cuvette temperature was ramped up from 5 to $65^{\circ} \mathrm{C}$ at a constant rate of $1{ }^{\circ} \mathrm{C} \mathrm{min}^{-1}$.

Leaf Traits: Measured leaves were subsequently photographed with a known scale and ImageJ was used to determine their projected area (Schneider et al., 2012). The leaves were dried at $65^{\circ} \mathrm{C}$ for a minimum of 48 hours and again weighed to determine leaf dry mass (g). Specific leaf area (SLA cm $\mathrm{g}^{-1}$ ) was calculated and used to determine mass-based respiratory fluxes from the area-based fluxes. Leaf water content (\%) and leaf dry matter content (LDMC g g ${ }^{-1}$ ) were calculated from the fresh and dry masses. Leaf nitrogen was estimated using the $\% \mathrm{~N}$ measured from these same trees, sampled at the same canopy locations in 2017 (Schmiege et al. pers

188 comm).

Data Analyses: The respiration temperature response curves were analyzed as in Heskel et al. (2016) by fitting a second-order polynomial model to the log transformed respiration rates 192 between 10 and $45^{\circ} \mathrm{C}$.

$$
\operatorname{LnR}=a+b T+c T^{2}
$$

Where $a$ represents the basal respiration rate (y-intercept), while $b$ and $c$ describe the slope and curvature of the response (Heskel et al. 2016). The respiration rate at a common temperature of $25^{\circ} \mathrm{C}\left(R_{25}\right)$ was also calculated and the temperature where the maximum respiration rate was reached $\left(T_{\max }\right)$ was recorded. The modeled temperature response was also used to quantify the possible effect of warming on respiration rates (in the absence of thermal acclimation - see justificaiton below), based on the current growing season average temperatures for the two sites and projections for end of the century warming (US Federal Government, 2021).

Respiration vs. temperature curves were fit to the polynomial model of Heskel et al., (2016) using R v. 3.6.3 (R Core Team, 2020). Due to the unequal sample size ( $\mathrm{BRF}=6$; $\mathrm{n}$ FTE $=18$ ), a one-way ANOVA was used to test our first hypothesis regarding respiration across the species range. To test our second hypotheses regarding the main effects of canopy position on respiration within each of the two sites, paired t-test were used to compare each of the model parameters $a, b$ and $c$ (see Equ. 1), and model predictions of $R_{25}$. All traits were transformed as necessary to fulfil assumptions of normality. To test our third hypothesis, we compared our model estimates with those of Heskel et al., (2016) by means of an independent sample t-test based on the mean, confidence intervals and sample size for the NLEv PFT (as reported in their Table 1). Our fourth hypothesis regarding the $\underline{T}_{\max }$ of respiration was tested similarly to hypotheses $1 \& 2$ described above. Finally, regression equations were used to assess the general relationships between leaf traits and leaf respiration, and in particular ability of leaf $\mathrm{N}$ (per unit leaf area) to predict the rate of respiration (Atkin et al., 2015). All data analysis other than the initial R/T curve fitting was done in Excel (version 16.51 for Mac, Microsoft, Redmond, Washington, U.S.A.) with both the Solver and RealStatistics (Release 7.6, Zaiontz 2021) add-ins.

221 Tree and leaf traits: The average tree in this study was $18.3 \pm 1.02 \mathrm{~cm}$ in DBH $(1.37 \mathrm{~m}$ from the 
diameter $(23.1 \pm 1.99$ vs. $16.6 \pm 0.68 \mathrm{~cm})$, but similar in height $(9.9 \pm 0.73$ vs. $9.36 \pm 0.41 \mathrm{~m})$ compared to the northern location trees.

225

The leaf dry matter content, leaf nitrogen content and leaf water content (LWC) did not differ by canopy position at either location, but LDMC was $32 \%$ lower, LWC was $37 \%$ higher, and leaf $\mathrm{N}$ was $25 \%$ higher at the southern location compared to the northern location (Table 1). The specific leaf area (SLA) of the upper canopy leaves was $23 \%$ lower than that of the lower canopy leaves at the southern location, which on average had $37 \%$ higher LWC than the northern location (Table 1).

Respiration temperature response curves: In all trees, respiration increased exponentially between 5 and $45^{\circ} \mathrm{C}$, then slowed briefly before increasing rapidly to a maximum rate $\left(R_{\max }\right)$ defining the $T_{\max }$ (Figure 2a). Measured respiration rates between 10 and $45^{\circ} \mathrm{C}$ were used to model the ecologically relevant response (Figure $2 \mathrm{~b}$ ). The global polynomial model of Heskel et al (2016) fit all $\log$ normal respiration temperature curves with an $r^{2} \geq 0.99$ (Figure 3). Overall, the three model coefficients averaged $-1.82 \pm 0.12,0.090 \pm 0.003$ and $-0.00030 \pm 0.0001(a, b$ and $c$ respectively, mean \pm SEM, Table 2 ). At the southern location, leaves from the top of the canopy had a $24 \%$ lower intercept (coefficient $a$ ), than leaves from the bottom of the canopy $(\mathrm{p}=0.04$, Table 2). Canopy position did not affect the model coefficients at the northern location. The temperature response of white spruce growing at the southern location is quite similar to the average model coefficients for the plant functional type to which this species belongs, needleleaved evergreen (NLEv, Heskel et al. 2016), and only the curvature (c) of the southern location upper canopy leaves was statistically different from the average NLEv response (Figure 3). However, the southern location measurements from both canopy positions were significantly different when compared to their counterparts from northern location (Figure 3). The differences include lower intercepts for both the BRF canopy positions, as well slight differences in both the slope and curvature of the upper canopy leaves. The response of respiration to temperature at the northern site was significantly different from the NLEv PFT response (higher $a$ ).

Respiration at a common temperature \& $R_{\max }$ : Across all samples at the southern location, the average rate of respiration at a common temperature of $25^{\circ} \mathrm{C}$ was $0.75 \pm 0.08 \mu \mathrm{mol} \mathrm{CO} \mathrm{m}^{-2}$ leaf area $\mathrm{s}^{-1}$, which is $68 \%$ lower than the average rate at the northern location $\left(2.35 \pm 0.88 \mu \mathrm{mol} \mathrm{CO} \mathrm{CO}_{2}\right.$ $\mathrm{m}^{-2}$ leaf area $\left.\mathrm{s}^{-1}\right)$. The rate differed significantly by canopy position at the southern but not the northern location. $R_{25}$ was $48 \%$ higher in upper canopy leaves than in lower canopy leaves $(0.90$ $\pm 0.09 \mu \mathrm{mol} \mathrm{m} \mathrm{m}^{-2} \mathrm{~s}^{-1}$ vs. $0.61 \pm 0.10 \mu \mathrm{mol} \mathrm{m} \mathrm{m}^{-2} \mathrm{~s}^{-1}$ ) from the southern location (Figure 4a). Due to significantly lower SLA of the southern location upper canopy leaves compared to the lower canopy leaves, there were no significant differences in the mass based $R_{25}$ (Figure $4 \mathrm{~b}$ ). Leaves from the southern location, at both canopy positions continued to respire until leaf temperature reached $58.5 \pm 0.5^{\circ} \mathrm{C}\left(T_{\max }\right)$ before respiration quickly decreased as the leaves died. This is a slightly higher, but statistically similar temperature to the $T_{\max }$ of northern location trees $\left(57.6 \pm 0.36^{\circ} \mathrm{C}\right)$. However, the maximum rate of respiration $\left(R_{\max }\right)$ of the upper canopy southern location leaves at $T_{\max }\left(7.43 \pm 0.78 \mu \mathrm{mol} \mathrm{m}^{-2} \mathrm{~s}^{-1}\right)$ was $40 \%$ higher than the $R_{\max }$ of the lower canopy leaves $\left(5.29 \pm 0.66 \mu \mathrm{mol} \mathrm{m} \mathrm{m}^{-2} \mathrm{~s}^{-1}\right)$, and the southern location average $R_{\max }$ was $59 \%$ lower than the northern location average, a difference of more than $9.3 \mu \mathrm{mol} \mathrm{CO} \mathrm{Cm}^{-2}$ leaf area s${ }^{-1}$ (Figure $4 \mathrm{c})$. None of the major respiratory parameters $\left(R_{25}, a\right.$ or $\left.R_{\max }\right)$ was significantly related to leaf $\mathrm{N}\left(\mathrm{mg} \mathrm{N} \mathrm{m}^{-2}\right)(\mathrm{p}>0.05$, data not shown), although the trend was always for increasing rates 
of respiration with increasing leaf $\mathrm{N}$. Estimated in situ rates of respiration at the average growing season temperature (June/July/August) were significantly higher at the northern location than they were at the southern location (indicated as solid vertical lines on Figure 5), as are the estimated rates for the projected end of century temperatures (indicated by dotted vertical lines on Figure 5).

\section{Discussion}

272 We found dramatic differences in white spruce leaf respiration across the species range, from New York State at the south-eastern edge of the distribution to the Forest Tundra Ecotone, more than $5000 \mathrm{~km}$ away in Arctic north-central AK. The differences are extreme, and represent a significant physiological response to changes in ambient environmental conditions. Across the vast range of this species, many environmental gradients/differences exist, including day length and associated effects on light energy, air and soil temperatures and moisture, and pollutant exposure and edaphic factors, all of which are moderated differently by the distinctive forest canopy structures of the sites. Of the above environmental factors, the response of white spruce foliage to air temperature is of particular interest for three reasons: 1) temperature is known to have strong effects on the rate of respiration (Heskel et al., 2016); 2) temperature is increasing rapidly and unevenly across the species range (warming is more rapid at high latitudes (Cohen et al., 2014; Huang et al., 2017); and 3) ecosystem models calculate the temperature response of respiration to scale over both time and space (Atkin et al., 2014; Heskel, Atkin, et al., 2016; Heskel et al., 2016; Huntingford et al., 2017a). Across the species range of white spruce, average growing season (June, July August) temperatures differ by nearly $6{ }^{\circ} \mathrm{C}$, from approximately 21 ${ }^{\circ} \mathrm{C}$ at the southern location (US Federal Government, 2021) to slightly less than $15^{\circ} \mathrm{C}$ at the northern location (Harris et al., 2020; Zepner et al., 2021). This $29 \%$ decrease in average temperature is associated with a tripling of the respiration rate in white spruce measured at a common temperature of $25^{\circ} \mathrm{C}$, and a doubling of the rate at the in situ average growing season temperature. The much higher rates of respiration at the northern range limit of this species do not support our first research hypothesis but may help explain not only why white spruce is not found further to the north, but also why the boreal forest biome transitions to tundra at these high northern latitudes (Griffin et al., 2021). Plants acclimated to cold temperatures often have higher rates of respiration measured at a common temperature and a steeper respiratory temperature response (Atkin \& Tjoelker, 2003; Körner, 1989; Reich \& Oleksyn, 2004) as a means to maintain metabolic function in cold environments. The high respiratory rates coupled with slow growth rates (Jensen et al., pers com) at the northern range limit suggest that northern trees experience large carbon losses that are likely related to high maintenance and other metabolic costs. These costs are not incurred in white spruce at the southern edge of its distribution.

The response of respiration to temperature in trees at either end of the species range provides additional insights into the regulation of respiration and the root cause of the observed differences. First, we find differences in the measured rates of respiration at both cold and warm temperatures. This is consistent with Type II acclimation (Atkin \& Tjoelker, 2003) and suggests that there are differences in respiratory capacity, efficiency or perhaps mitochondrial numbers and structure (Atkin \& Tjoelker, 2003; Klikoff, 1966; Kornfeld et al., 2013; Miroslavov \& Kravkina, 1991; Patterson et al., 2018). Second, the measured $T_{\max }$ of white spruce needle respiration does not differ significantly across the entire range. This indicates that overall thermal tolerance is not plastic but a fixed species trait in white spruce (Heskel et al., 2014; O'Sullivan et al., 2013, 2017). Third, we find differences in the temperature response of respiration across the 
species range, with northern white spruce also exhibiting a significantly different response to that of the needle leaved evergreen plant functional type. This suggests that the northern range limit is an extremely challenging environment for this species, and that the high respiration rates may be affecting leaf carbon balance and ultimately tree survival (Heskel et al., 2016; Huntingford et al., 2017b; Patterson et al., 2018). And fourth, despite the indication of a Type II acclimation response (Atkin \& Tjoelker, 2003) the adjustments in respiratory physiology do not result in homeostasis with regards to maintaining observed rates of respiration at the local temperatures during the growing season. Rates of respiration at the northern edge of the species range are extremely high and respond strongly to temperature, most likely stemming from biochemical and physiological responses to the extreme environmental conditions of the Arctic.

We gained further insights into the response of white spruce to local environmental conditions across its range by examining leaf traits and the relationships between leaf traits and respiratory physiology. Needles from the northern edge of the species distribution tend to be thicker, or perhaps denser, than needles from the southern location, likely reflecting large differences in ambient temperatures (Atkin et al., 2006; Rosbakh et al., 2015). Increasing leaf structure is potentially adaptive in the harsh environmental conditions at the arctic treeline where, in addition to cold temperatures, leaves must survive high winds and abrasion, prolonged winters and the possibility of large snow or ice loads while remaining metabolically active for many years. While we found that variation in leaf structural characteristics were consistent with expected relationships with cold temperatures, the biochemical characteristics were not. Leaf nitrogen usually correlates negatively to temperature (Yin, 1993), and positively to leaf respiration (Atkin et al., 2015) and latitude (Körner, 1989) yet these trends did not hold across the species range of white spruce. The small difference in leaf nitrogen at the northern compared to the southern range limit likely reflects the effects of the environment (e.g. temperature, hydrology, permafrost dynamics and bedrock geology, (Nadelhoffer et al., 1991; Schimel et al., 2004) and biogeochemistry (limited nitrogen fixation, slow decomposition rates, rapid uptake rates and microbial competition (Schimel \& Chapin, 1996; Schimel \& Bennett, 2004; Yano et al., 2010)) on nitrogen availability and certainly suggests the presence of nitrogen limitation at the northern location. Despite lack of a statistical difference in leaf $\mathrm{N}$ content, we found that the rate of white spruce needle respiration and its response to temperature remained extremely high at the northern location compared to the southern location, limiting the effectiveness of leaf $\mathrm{N}$ as a proxy of respiration (Atkin et al. 2015). The patterns in leaf traits suggest the general adaptative strategy in white spruce necessary to survive harsh northern conditions, and implicates the local environmental conditions as directly and indirectly driving the respiratory physiology across the species range.

We found support for our second hypothesis, that needles from the top of the tree would have higher rates of respiration than needles from the bottom of the tree at the southern range limit where canopy complexity creates resource gradients. The nature of the tree crown and the forest canopy differs significantly at our two sites. The southern location trees are strongly conical and compete for above ground resources in a mostly closed canopy surrounded by deciduous hardwood species. The FTE trees, however, are more cylindrical and arranged in mostly open canopies composed of individual trees or small groups of trees with only limited competition for space and aboveground resources such as light. As a result, strong intra canopy light gradients exist at the southern location but are much less pronounced at the northern location. Light, VPD, 
wind and air temperature microclimates could all be affected by these differences in canopy structure (Walcroft et al., 2005; Whitehead et al., 2001; Whitehead, Walcroft, et al., 2004), but light is the most plausible driver of the observed respiratory response (similar to Bond et al., 1999). The upper canopy leaves at the southern location receive full light and as a result have higher photosynthetic rates than the lower canopy leaves which experience self-shading and generally lower ambient light conditions (Schmiege et al., pers com). Higher photosynthetic rates and more rapid growth in the upper canopy require higher respiration to support the ensuing growth and maintenance costs of these needles (Bond et al., 1999; Griffin et al., 2001, 2002; Tissue et al., 2002; Whitehead et al., 2004). By contrast, the combination of the open canopy, low sun angles and narrow unbranching crown morphology of white spruce at the northern location has the effect of homogenizing the light environment, and thus equalizing both photosynthetic capacities, and the rates of respiration throughout the canopy. Clearly spruce trees at either end of the species distribution must dynamically respond and adapt to different environmental conditions over multiple spatial and temporal scales. However, our findings show that it is the interplay between the environment and tree form and function that contributes to, and ultimately determines, the geographic location of the species range. At the southern edge of its range, white spruce exhibits unique respiratory responses in the upper vs lower canopy needles to persist. At the northern limits, the unequal distribution of metabolic activity amongst the different canopy positions is not observed and presumably not needed.

Climate change has, and will continue, to increase air temperature across the white spruce range (Tamarin-Brodsky et al., 2020). This may increase rates of respiration and exacerbate increases in respiratory carbon loss from the southern to the northern range limits of this species. The short-term temperature response curves presented here can be cautiously used to infer how respiration might change with continued warming. We note that thermal acclimation of respiration could directly alter the predicted response (Atkin et al., 2008; Slot \& Kitajima, 2015; Vanderwel et al., 2015), most likely lessening the effect of climate warming. However, the noted lack of thermal acclimation of respiration in this species implies that the short-term respiration temperature response may be used to predict the long-term effect of climate warming in white spruce (Benomar et al., 2016). Using the current growing season temperature and the predicted rate of temperature increase by the end of the century (U.S. Climate Resilience Toolkit Climate Explorer), we calculate that white spruce respiration may increase by $67 \%$ at the northern range limit regardless of canopy location and by $53 \%$ at the southern range limit, where the upper canopy needles are likely to increase more than the lower canopy (46 vs. $60 \%$ respectively). These are massive estimated changes in the leaf carbon flux to the atmosphere that, if unmatched by similar increases in photosynthesis or mediated by thermal acclimation, would have dramatic effects on leaf carbon balance (Ow et al., 2008; Ow et al., 2008). Combining the $R_{25}$ rates with these projected rates of increase suggests that any increase in respiration is likely to be more detrimental to the carbon balance of white spruce at the northern range limit than at the southern range limit. The ecological effects of these physiological changes on the competitiveness of this species and the future species range are unknown but clearly the metabolic adjustments needed to respond to the changing environmental conditions are likely to play a role. We suggest these effects are at least as severe, if not significantly more so, at the northern end of the range limit than they are at the southern edge. This calls into question the suggestions (ACIA 2005; Zhang et

403 al. 2013; Pearson et al. 2013), that species migrations will tend to shift species ranges north and more specifically to move the arctic treeline north in response to climate change. 


\section{Conclusions}

The natural distribution of white spruce extends not just across strong environmental gradients, but also to the very limit of tree growth form. North of its current range limit, not only is white spruce not found, but neither are trees of any species. The results presented here may help explain these linked observations. We clearly show that respiration rates of white spruce at the northern range limit are not only higher than those from trees growing at the southern range limit, but that these rates are extreme. Furthermore, we show that canopy position has a strong influence on the distribution of respiratory activity at the southern range limit but not at the northern range limit, a pattern that likely reflects differences in metabolic activity driven by light. Despite the large differences in respiration, leaf traits in this species often remain constant across the species range. Additionally, when leaf traits do change, they do not explain patterns in respiratory activity. As a result, common techniques used to estimate respiration, such as predictions based on leaf nitrogen, were ineffective. The model of Heskel et al., (2016) was successfully fit to our data and demonstrates that the temperature response of respiration at the southern end of the species distribution is statistically indistinguishable from the NLEv tree plant functional type used in their global survey. In contrast, the northern range limit trees have much higher rates of respiration and differ significantly from the NLEv PFT. Our work supports the conclusion of Griffin et al. (2021), that white spruce needles at the northern range edge respire at what are likely the species extreme limits, and that this carbon cost likely contributes to the location of northern treeline. Using the short-term temperature response curves to constrain the potential response of respiration to predicted end-of-the-century warming, we show that respiration will have a significant impact on leaf carbon balance that is likely to contribute to future range limits of this species. We question the assertion that species like white spruce will simply shift their range distributions northward in response to warming and suggest that, without a detailed understanding of the myriad ways photosynthesis, respiration and growth will respond to changing climatic conditions, range shifts will be difficult to predict.

\section{Conflict of Interest}

433 The authors declare that the research was conducted in the absence of any commercial or 434 financial relationships that could be construed as a potential conflict of interest.

\section{Author Contributions}

436 K.L.G., S.C.S., N.B., L.A.V. and J.U.H.E. designed the research. They were assisted in data 437 collection by Z.M.G. \& S.B.. S.C.S, Z.M.G. \& K.L.G. analyzed the data. K.L.G wrote the first 438 draft of the manuscript. All authors contributed to the revisions, editing and submission of the 439 final manuscript.

\section{Acknowledgements}

441 We thank Matt Brady and the Black Rock Forest staff for logical and field support. This work 442 was supported by NASA ABoVE grant NNX15AT86A. 


\section{Literature Cited}

ACIA. (2005). Arctic climate impact assessment scientific report. Fairbanks (USA): University of Alaska, Cambridge University Press. 1020 pp.

Arguez, A., Durre, I., Applequist, S., Squires, M., Vose, R., Yin, X., \& Bilotta, R. (2010). NOAA's U.S. Climate Normals (1981-2010).

Atkin, O. K., Atkinson, L. J., Fisher, R. a., Campbell, C. D., Zaragoza-Castells, J., Pitchford, J. W., Woodward, F. I., \& Hurry, V. (2008). Using temperature-dependent changes in leaf scaling relationships to quantitatively account for thermal acclimation of respiration in a coupled global climate-vegetation model. Global Change Biology, 14(11), 2709-2726. https://doi.org/10.1111/j.1365-2486.2008.01664.x

Atkin, O. K., Bloomfield, K. J., Reich, P. B., Tjoelker, M. G., Asner, G. P., Bonal, D., Bönisch, G., Bradford, M. G., Cernusak, L. A., Cosio, E. G., Creek, D., Crous, K. Y., Domingues, T. F., Dukes, J. S., Egerton, J. J. G., Evans, J. R., Farquhar, G. D., Fyllas, N. M., Gauthier, P. P. G., ... Zaragoza-Castells, J. (2015). Global variability in leaf respiration in relation to climate, plant functional types and leaf traits. New Phytologist, 206(2), 614-636. https://doi.org/10.1111/nph.13253

Atkin, O. K., Loveys, B. R., Atkinson, L. J., \& Pons, T. L. (2006). Phenotypic plasticity and growth temperature: understanding interspecific variability. Journal of Experimental Botany, 57(2), 267-281. https://doi.org/10.1093/jxb/erj029

Atkin, O. K., Meir, P., \& Turnbull, M. H. (2014). Improving representation of leaf respiration in large-scale predictive climate-vegetation models. New Phytologist, 202(3), 743-748. https://doi.org/10.1111/nph.12686

Atkin, O. K., \& Tjoelker, M. G. (2003). Thermal acclimation and the dynamic response of plant respiration to temperature. Trends in Plant Science, 8(7), 343-351. https://doi.org/10.1016/S1360-1385(03)00136-5

Awada, T., \& Redmann, R. E. (2000). Acclimation to light in planted and naturally regenerated populations of white spruce seedlings. Canadian Journal of Botany-Revue Canadienne De Botanique, 78(12), 1495-1504. https://doi.org/10.1139/b00-121

Benomar, L., Lamhamedi, M. S., Pepin, S., Rainville, A., Lambert, M. C., Margolis, H. A., Bousquet, J., \& Beaulieu, J. (2018). Thermal acclimation of photosynthesis and respiration of southern and northern white spruce seed sources tested along a regional climatic gradient indicates limited potential to cope with temperature warming. Annals of Botany, 121(3), 443-457. https://doi.org/10.1093/aob/mcx174

Benomar, L., Lamhamedi, M. S., Rainville, A., Beaulieu, J., Bousquet, J., \& Margolis, H. A. (2016). Genetic adaptation vs. ecophysiological plasticity of photosynthetic-related traits in young Picea glauca trees along a regional climatic gradient. Frontiers in Plant Science, 7(FEB2016), 1-15. https://doi.org/10.3389/fpls.2016.00048 
Bond, B. J., Farnsworth, B. T., Coulombe, R. A., \& Winner, W. E. (1999). Foliage physiology and biochemistry in response to light gradients in conifers with varying shade tolerance. Oecologia, 120(2), 183-192.

Brown, J. H., Stevens, G. C., \& Kaufman, D. M. (1996). The geographic range: Size, shape, boundaries, and internal structure. Annual Review of Ecology and Systematics, 27, 597-623. https://doi.org/10.1146/annurev.ecolsys.27.1.597

Casazza, G., Barberis, G., \& Minuto, L. (2005). Ecological characteristics and rarity of endemic plants of the Italian Maritime Alps. Biological Conservation, 123(3), 361-371. https://doi.org/10.1016/j.biocon.2004.12.005

Cohen, J., Screen, J. A., Furtado, J. C., Barlow, M., Whittleston, D., Coumou, D., Francis, J., Dethloff, K., Entekhabi, D., Overland, J., \& Jones, J. (2014). Recent Arctic amplification and extreme mid-latitude weather. Nature Geoscience, 7(9), 627-637. https://doi.org/10.1038/ngeo2234

Criddle, R. S., Church, J. N., Smith, B. N., \& Hansen, L. D. (2003). Fundamental causes of the global patterns of species range and richness. Russian Journal of Plant Physiology, 50(2), 192-199. https://doi.org/10.1023/a:1022969029867

Eitel, J. U. H. J. U. H., Maguire, A. J. A. J., Boelman, N., Vierling, L. A. L. A., Griffin, K. L. K. L., Jensen, J., Magney, T. S. T. S., Mahoney, P. J. P. J., Meddens, A. J. H. A. J. H., Silva, C., \& Sonnentag, O. (2019). Proximal remote sensing of tree physiology at northern treeline: Do late-season changes in the photochemical reflectance index (PRI) respond to climate or photoperiod? Remote Sensing of Environment, 221(October 2018), 340-350. https://doi.org/10.1016/j.rse.2018.11.022

Gaston, K. J. (1996). Species-range-size distributions: Patterns, mechanisms and implications. Trends in Ecology \& Evolution, 11(5), 197-201. https://doi.org/10.1016/01695347(96)10027-6

Griffin, K. L., Tissue, D. T., Turnbull, M. H., Schuster, W., \& Whitehead, D. (2001). Leaf dark respiration as a function of canopy position in Nothofagus fusca trees grown at ambient and elevated $\mathrm{CO}_{2}$ partial pressures for 5 years. Functional Ecology, 15(4), 497-505. https://doi.org/10.1046/j.0269-8463.2001.00539.x

Griffin, K. L., Turnbull, M., \& Murthy, R. (2002). Canopy position affects the temperature response of leaf respiration in Populus deltoides. New Phytologist, 154(3), 609-619. https://doi.org/10.1046/j.1469-8137.2002.00410.x

Griffin, K.L., Schmiege, S.C., Bruner, S.G., Boelman, N.T., Vierling, L.A., Eitel J.U.H. (2021) High Leaf Respiration Rates May Limit the Success of White Spruce Saplings growing in The Kampfzone at The Arctic Treeline. Frontiers in Plant Science - Plant Physiology, in review - bioRxiv 2021.08.10.455813; doi: https://doi.org/10.1101/2021.08.10.455813

Harris, I., Jones, P., Osborn, T. (2020) CRU TS4.04: Climatic Research Unit (CRU) Time-Series (TS) Version 4.04 of High-resolution Gridded Data of Month-by-Month Variation in 
Climate (Jan. 1901-Dec. 2019).In Unit UoEACR. East Anglia: Centre for Environmental

Heskel, M. A., Atkin, O. K., O’Sullivan, O. S., Reich, P., Tjoelker, M. G., Weerasinghe, L. K., Penillard, A., Egerton, J. J. G., Creek, D., Bloomfield, K. J., Xiang, J., Sinca, F., Stangl, Z. R., Martinez-De La Torre, A., Griffin, K. L., Huntingford, C., Hurry, V., Meir, P., \& Turnbull, M. H. (2016). Empirical versus process-based approaches to modeling temperature responses of leaf respiration. Proceedings of the National Academy of Sciences of the United States of America, 113(41), E5996-E5997. https://doi.org/10.1073/pnas.1612904113

Heskel, M. A., Greaves, H. E., Turnbull, M. H., O’Sullivan, O. S., Shaver, G. R., Griffin, K. L., \& Atkin, O. K. (2014). Thermal acclimation of shoot respiration in an Arctic woody plant species subjected to 22 years of warming and altered nutrient supply. Global Change Biology, 20(8), 2618-2630. https://doi.org/10.1111/gcb.12544

Heskel, M. A., O’Sullivan, O. S., Reich, P. B., Tjoelker, M. G., Weerasinghe, L. K., Penillard, A., Egerton, J. J. G., Creek, D., Bloomfield, K. J., Xiang, J., Sinca, F., Stangl, Z. R., Martinez-De La Torre, A., Griffin, K. L., Huntingford, C., Hurry, V., Meir, P., Turnbull, M. H., \& Atkin, O. K. (2016). Convergence in the temperature response of leaf respiration across biomes and plant functional types. Proceedings of the National Academy of Sciences of the United States of America, 113(14), 3832-3837. https://doi.org/10.1073/pnas.1520282113

Hijmans, R. J., \& Graham, C. H. (2006). The ability of climate envelope models to predict the effect of climate change on species distributions. Global Change Biology, 12(12), 22722281. https://doi.org/10.1111/j.1365-2486.2006.01256.x

Huang, J. B., Zhang, X. D., Zhang, Q. Y., Lin, Y. L., Hao, M. J., Luo, Y., Zhao, Z. C., Yao, Y., Chen, X., Wang, L., Nie, S. P., Yin, Y. Z., Xu, Y., \& Zhang, J. S. (2017). Recently amplified arctic warming has contributed to a continual global warming trend. Nature Climate Change, 7(12), 875-879. https://doi.org/10.1038/s41558-017-0009-5

Huntingford, C., Atkin, O. K., Martinez-De La Torre, A., Mercado, L. M., Heskel, M. A., Harper, A. B., Bloomfield, K. J., O’Sullivan, O. S., Reich, P. B., Wythers, K. R., Butler, E. E., Chen, M., Griffin, K. L., Meir, P., Tjoelker, M. G., Turnbull, M. H., Sitch, S., Wiltshire, A., \& Malhi, Y. (2017). Implications of improved representations of plant respiration in a changing climate. Nature Communications, 8(1). https://doi.org/10.1038/s41467-01701774-z

Klikoff, L. G. (1966). Temperature dependence of the oxidative rates of mitochondria in Danthonia intermedia, Penstemon davidsonii and Sitanion hystrix. Nature, 212(5061), 529530.

Körner, C. (1989). The nutritional status of plants from high altitudes. Oecologia, 81(3), 379391. 
Kornfeld, A., Heskel, M., Atkin, O. K., Gough, L., Griffin, K. L., Horton, T. W., \& Turnbull, M. H. (2013). Respiratory flexibility and efficiency are affected by simulated global change in Arctic plants. New Phytologist, 197(4), 1161-1172. https://doi.org/10.1111/nph.12083

Kruckeberg, A. R., \& Rabinowitz, D. (1985). BIOLOGICAL ASPECTS OF ENDEMISM IN HIGHER-PLANTS. Annual Review of Ecology and Systematics, 16, 447-479. https://doi.org/10.1146/annurev.es.16.110185.002311

Kunin, W. E., \& Gaston, K. J. (1993). The biology of rarity - patterns, causes and consequences. Trends in Ecology \& Evolution, 8(8), 298-301. https://doi.org/10.1016/01695347(93)90259-r

Lambers, H., \& Oliveira, R. S. (2019). Plant physiological ecology. In Plant Physiological Ecology. Springer US. https://doi.org/10.1007/978-3-030-29639-1

Lavergne, S., Thompson, J. D., Garnier, E., \& Debussche, M. (2004). The biology and ecology of narrow endemic and widespread plants: a comparative study of trait variation in 20 congeneric pairs. Oikos, 107(3), 505-518. https://doi.org/10.1111/j.00301299.2004.13423.x

Lowry, E., \& Lester, S. E. (2006). The biogeography of plant reproduction: Potential determinants of species' range sizes. Journal of Biogeography, 33(11), 1975-1982. https://doi.org/10.1111/j.1365-2699.2006.01562.x

Malanson, G. P., Westman, W. E., \& Yan, Y. L. (1992). Realized versus fundamental niche functions in a model of chaparral response to climatic-change. Ecological Modelling, 64(4), 261-277. https://doi.org/10.1016/0304-3800(92)90026-b

Man, R. Z., \& Lieffers, V. J. (1997). Seasonal photosynthetic responses to light and temperature in white spruce (Picea glauca) seedlings planted under an aspen (Populus tremuloides) canopy and in the open. Tree Physiology, 17(7), 437-444.

Marion, G. M., Hastings, S. J., Oberbauer, S. F., \& Oechel, W. C. (1989). Soil-plant element relationships in a tundra ecosystem. Ecography, 12(3), 296-303. https://doi.org/10.1111/j.1600-0587.1989.tb00849.x

McNown, R. W., \& Sullivan, P. F. (2013). Low photosynthesis of treeline white spruce is associated with limited soil nitrogen availability in the Western Brooks Range, Alaska. Functional Ecology, 27(3), 672-683. https://doi.org/10.1111/1365-2435.12082

Miller, A. E., Schimel, J. P., Sickman, J. O., Skeen, K., Meixner, T., \& Melack, J. M. (2009). Seasonal variation in nitrogen uptake and turnover in two high-elevation soils: mineralization responses are site-dependent. Biogeochemistry, 93(3), 253-270. https://doi.org/10.1007/s10533-009-9301-4

Miroslavov, E. A., \& Kravkina, I. M. (1991). Comparative analysis of chloroplasts and mitochondria in leaf chlorenchyma from mountain plants grown at different altitudes. Annals of Botany, 68(3), 195-200. 
Nadelhoffer, K. J., Giblin, A. E., Shaver, G. R., \& Laundre, J. A. (1991). Effects of temperature and substrate quality on element mineralization in six arctic soils. Ecology, 72(1), 242-253.

O’Sullivan, O. S., Heskel, M. A., Reich, P. B., Tjoelker, M. G., Weerasinghe, L. K., Penillard, A., Zhu, L., Egerton, J. J. G., Bloomfield, K. J., Creek, D., Bahar, N. H. A., Griffin, K. L., Hurry, V., Meir, P., Turnbull, M. H., \& Atkin, O. K. (2017). Thermal limits of leaf metabolism across biomes. Global Change Biology, 23(1), 209-223. https://doi.org/10.1111/gcb.13477

O'Sullivan, O. S., Weerasinghe, K., Evans, J. R., Egerton, J. J. G., Tjoelker, M. G., \& Atkin, O. K. (2013). High-resolution temperature responses of leaf respiration in snow gum (Eucalyptus pauciflora) reveal high-temperature limits to respiratory function. Plant Cell and Environment, 36(7), 1268-1284. https://doi.org/10.1111/pce.12057

Ow, L. F., Griffin, K. L., Whitehead, D., Walcroft, A. S., \& Turnbull, M. H. (2008a). Thermal acclimation of leaf respiration but not photosynthesis in Populus deltoides $\mathrm{x}$ nigra. New Phytologist, 178(1), 123-134. https://doi.org/10.1111/j.1469-8137.2007.02357.x

Ow, L. F., Whitehead, D., Walcroft, A. S., \& Turnbull, M. H. (2008b). Thermal acclimation of respiration but not photosynthesis in Pinus radiata. Functional Plant Biology, 35(6), 448461. https://doi.org/10.1071/FP08104

Patterson, A. E., Arkebauer, R., Quallo, C., Heskel, M. A., Li, X. M., Boelman, N., \& Griffin, K. L. (2018). Temperature response of respiration and respiratory quotients of 16 co-occurring temperate tree species. Tree Physiology, 38(9), 1319-1332.

Pearson, R.G,, Phillips, S.J., Loranty, M.M,. Beck, P.S.A., Damoulas, T., Knight, S.J., Goetz, S.J. (2013). Shifts in Arctic vegetation and associated feedbacks under climate change. Nature Climate Change, 3, 673-677.

Prentice, I. C., Cramer, W., Harrison, S. P., Leemans, R., Monserud, R. A., \& Solomon, A. M. (1992). A global biome model based on plant physiology and dominance, soil properties and climate. Journal of Biogeography, 19(2), 117-134. https://doi.org/10.2307/2845499

Prud'Homme, G. O., Lamhamedi, M. S., Benomar, L., Rainville, A., DeBlois, J., Bousquet, J., Beaulieu, J., Prud'Homme, G. O., Lamhamedi, M. S., Benomar, L., Rainville, A., DeBlois, J., Bousquet, J., \& Beaulieu, J. (2018). Ecophysiology and growth of white spruce seedlings from various seed sources along a climatic gradient support the need for assisted migration. Frontiers in Plant Science, 8(January), 1-17. https://doi.org/10.3389/fpls.2017.02214

Reich, P. B., \& Oleksyn, J. (2004). Global patterns of plant leaf N and P in relation to temperature and latitude. Proceedings of the National Academy of Sciences of the United States of America, 101(30), 11001-11006. https://doi.org/10.1073/pnas.0403588101

Rosbakh, S., Römermann, C., \& Poschlod, P. (2015). Specific leaf area correlates with temperature: new evidence of trait variation at the population, species and community levels. Alpine Botany, 125(2), 79-86. https://doi.org/10.1007/s00035-015-0150-6 
Schimel, J. P., \& Bennett, J. (2004). Nitrogen mineralization: Challenges of a changing paradigm. Ecology, 85(3), 591-602.

Schimel, J. P., Bilbrough, C., \& Welker, J. A. (2004). Increased snow depth affects microbial activity and nitrogen mineralization in two Arctic tundra communities. Soil Biology \& Biochemistry, 36(2), 217-227. https://doi.org/10.1016/j.soilbio.2003.09.008

Schimel, J. P., Chapin, F. S., \& Stuart Chapin, F. (1996). Tundra plant uptake of amino acid and $\mathrm{NH}_{4}{ }^{+}$nitrogen in situ: Plants compete well for amino acid N. Ecology, 77(7), 2142-2147. https://doi.org/10.2307/2265708

Schmiege, S. C., Buckley, B. M., Stevenson, D. W., Heskel, M. A., Cuong, T. Q., Nam, L., \& Griffin, K. L. (2021). Respiratory temperature responses of tropical conifers differ with leaf morphology. Functional Ecology. https://doi.org/10.1111/1365-2435.13814

Schneider, C. A., Rasband, W. S., \& Eliceiri, K. W. (2012). NIH Image to ImageJ: 25 years of image analysis. Nature Methods, 9(7), 671-675. https://doi.org/10.1038/nmeth.2089

Schuster, W. S. F., Griffin, K. L., Roth, H., Turnbull, M. H., Whitehead, D., \& Tissue, D. T. (2008). Changes in composition, structure and aboveground biomass over seventy-six years (1930-2006) in the Black Rock Forest, Hudson Highlands, southeastern New York State. Tree Physiology, 28(4). https://doi.org/10.1093/treephys/28.4.537

Slot, M., \& Kitajima, K. (2015). General patterns of acclimation of leaf respiration to elevated temperatures across biomes and plant types. Oecologia, 177(3), 885-900. https://doi.org/10.1007/s00442-014-3159-4

Stebbins, G. L. (1942). The genetic approach to problems of rare and endemic species. Madrono, 6(8), 241-258.

Stinziano, J. R., \& Way, D. A. (2017). Autumn photosynthetic decline and growth cessation in seedlings of white spruce are decoupled under warming and photoperiod manipulations. Plant Cell and Environment, 40(8), 1296-1316. https://doi.org/10.1111/pce.12917

Sutton, R. F. (1969). The Silvics of White Spruce (Picea glauca (Moench) Voss) (Vol. 1250). Forest Research Division, Forestry Branch, Canada.

Tamarin-Brodsky, T., Hodges, K., Hoskins, B. J., \& Shepherd, T. G. (2020). Changes in Northern Hemisphere temperature variability shaped by regional warming patterns. Nature Geoscience, 13(6), 414-421.

Tissue, D. T., Lewis, J. D., Wullschleger, S. D., Amthor, J. S., Griffin, K. L., \& Anderson, O. R. (2002). Leaf respiration at different canopy positions in sweetgum (Liquidambar styraciflua) grown in ambient and elevated concentrations of carbon dioxide in the field. Tree Physiology, 22(15-16), 1157-1166. https://doi.org/10.1093/treephys/22.15-16.1157

US Federal Government. (2021). U.S. Climate Resilience Toolkit Climate Explorer. [Online] https://crt-climate-explorer.nemac.org/ Accessed August 2021. 
US Geological Survey. (1999). Digital representation of “Atlas of United States Trees” by Elbert L. Little Jr. US Geological Survey Professional Paper 1650.

Valentini, R., Matteucci, G., Dolman, A. J., Schulze, E. D., Rebmann, C., Moors, E. J., Granier, A., Gross, P., Jensen, N. O., Pilegaard, K., Lindroth, A., Grelle, A., Bernhofer, C., Grunwald, T., Aubinet, M., Ceulemans, R., Kowalski, A. S., Vesala, T., Rannik, U., ... Jarvis, P. G. (2000). Respiration as the main determinant of carbon balance in European forests. Nature, 404(6780), 861-865. https://doi.org/10.1038/35009084

Vanderwel, M. C., Slot, M., Lichstein, J. W., Reich, P. B., Kattge, J., Atkin, O. K., Bloomfield, K. J., Tjoelker, M. G., \& Kitajima, K. (2015). Global convergence in leaf respiration from estimates of thermal acclimation across time and space. New Phytologist, 207(4), 10261037. https://doi.org/10.1111/nph.13417

Walcroft, A. S., Brown, K. J., Schuster, W. S. F., Tissue, D. T., Turnbull, M. H., Griffin, K. L., \& Whitehead, D. (2005). Radiative transfer and carbon assimilation in relation to canopy architecture, foliage area distribution and clumping in a mature temperate rainforest canopy in New Zealand. Agricultural and Forest Meteorology, 135(1-4), 326-339. https://doi.org/10.1016/j.agrformet.2005.12.010

Watson, H. C. (1833). Observations on the affinities between plants and subjacent rocks. Magazine of Natural History, 6, 424-427.

Weger, H. G., \& Guy, R. D. (1991). Cytochrome and alternative pathway respiration in white spruce (Picea glauca) roots - effects of growth and measurement temperature. Physiologia Plantarum, 83(4), 675-681.

Whitehead, D., Griffin, K. L., Turnbull, M. H., Tissue, D. T., Engel, V. C., Brown, K. J., Schuster, W. S. F., \& Walcroft, A. S. (2004). Response of total night-time respiration to differences in total daily photosynthesis for leaves in a Quercus rubra L. canopy: Implications for modelling canopy $\mathrm{CO}_{2}$ exchange. Global Change Biology, 10(6), 925-938. https://doi.org/10.1111/j.1529-8817.2003.00739.x

Whitehead, D., Leathwick, J. R., \& Walcroft, A. S. (2001). Modeling annual carbon uptake for the indigenous forests of New Zealand. Forest Science, 47(1), 9-20. https://doi.org/10.1093/forestscience/47.1.9

Whitehead, D., Walcroft, A. S., Griffin, K. L., Tissue, D. T., Turnbull, M. H., Engel, V., Brown, K. J., \& Schuster, W. S. F. (2004). Scaling carbon uptake from leaves to canopies: Insights from two forests with contrasting properties. In Forests at the land-atmosphere interface (pp. 231-254).

Yano, Y., Shaver, G. R., Giblin, A. E., Rastetter, E. B., \& Nadelhoffer, K. J. (2010). Nitrogen dynamics in a small arctic watershed: Retention and downhill movement of ${ }^{15} \mathrm{~N}$. Ecological Monographs, 80(2), 331-351. https://doi.org/10.1890/08-0773.1

Yin, X. (1993). Variation in foliar nitrogen concentration by forest type and climatic gradients in North America. Canadian Journal of Forest Research, 23(8), 1587-1602. 
Zepner, L., Karrasch, P., Wiemann, F., Bernard, L. (2021) ClimateCharts.net - an interactive climate analysis web platform. International Journal of Digital Earth 14(3): 338-356.

Zhang, W., Miller, P.A., Smith, B., Wania, R., Koenigk, T., Döscher, R. (2013). Tundra

709 shrubification and tree-line advance amplify arctic climate warming: results from an

710 individual-based dynamic vegetation model. Environ Res Lett. 8, 034023.

711 
Tables

Table 1. Top of canopy leaf and bottom of canopy leaf characteristics of Picea glauca trees growing at either the south-eastern edge of the species range limit in Black Rock Forest, NY USA, or at the northern edge at the Forest Tundra Ecotone (FTE) in northcentral Alaska, USA. $\mathrm{DBH}=$ diameter at breast height $(1.37 \mathrm{~m}), \mathrm{SLA}=$ specific leaf area, LDMC $=$ leaf dry matter content (g dry mass g-1 fresh mash, $\mathrm{LWC}=$ leaf water content and $\mathrm{N}=$ leaf nitrogen \%. ${ }^{*}$ Leaf nitrogen data collected from the same trees in 2017, (Schmiege et al. pers com). Lowercase letters following the canopy position means (within a site) and uppercase letters following the location means (across the canopy positions) denote statistically significant differences $(\mathrm{p}<0.05)$. $\mathrm{n}=6-47$, all values mean \pm 1 standard error.

\begin{tabular}{|c|c|c|c|c|c|c|}
\hline & $\begin{array}{c}D B H \\
\mathrm{~cm}\end{array}$ & $\begin{array}{c}\text { Height } \\
m\end{array}$ & $\begin{array}{c}S L A \\
\mathrm{~cm}^{2} \mathrm{~g}^{-1}\end{array}$ & LDMC & $\begin{array}{c}\angle W C \\
\%\end{array}$ & $\begin{array}{c}N^{*} \\
\%\end{array}$ \\
\hline BRF & $23.1 \pm 1.99$ B & $9.9 \pm 0.73 \mathrm{~A}$ & $61.34 \pm 4.53$ B & $368.93 \pm 6.79 \mathrm{~A}$ & $63.1 \pm 0.78 \mathrm{~B}$ & $1.10 \pm 0.04 \mathrm{~B}$ \\
\hline Upper Canopy & - & - & $53.19 \pm 4.43 a$ & $375.99 \pm 5.27 \mathbf{a}$ & $62.4 \pm 0.53 \mathrm{a}$ & $1.11 \pm 0.03 \mathbf{b}$ \\
\hline Lower Canopy & - & - & $69.50 \pm 6.62$ b & $361.87 \pm 12.45$ a & $63.8 \pm 1.25 \mathrm{a}$ & $1.10 \pm 0.08 b$ \\
\hline FTE & $16.6 \pm 0.68 \mathrm{~A}$ & $9.36 \pm 0.41 \mathrm{~A}$ & $44.90 \pm 1.46 \mathrm{~A}$ & $540.03 \pm 3.15 \mathrm{~B}$ & $46.0 \pm 0.32 \mathrm{~A}$ & $0.88 \pm 0.10 \mathrm{~A}$ \\
\hline Upper Canopy & - & - & $44.15 \pm 3.51 \mathrm{a}$ & $542.19 \pm 4.55 a$ & $45.8 \pm 0.46 \mathrm{a}$ & $0.79 \pm 0.11 \mathrm{a}$ \\
\hline Lower Canopy & - & - & $45.64 \pm 1.46 \mathrm{a}$ & $537.99 \pm 4.44$ a & $46.2 \pm 0.44$ a & $0.96 \pm 0.06 a$ \\
\hline All Trees & $18.31 \pm 1.02$ & $9.47 \pm 0.46$ & $53.12 \pm 1.88$ & $496.34 \pm 11.37$ & $50.4 \pm 1.14$ & $0.99 \pm 0.05$ \\
\hline
\end{tabular}

Table 2. Model parameters fit to the measured high-resolution leaf respiration temperature response curves collected from either the top of canopy leaves or bottom of canopy leaves of Picea glauca trees growing at either the southern edge of the species range limit in Black Rock Forest, NY USA, or the northern edge of the species range limit in the Forest Tundra Ecotone (FTE) in northcentral AK, USA. Lowercase letters following the canopy position means and uppercase letters following the location means denote statistically significant differences $(\mathrm{p}<0.05) . \mathrm{n}=6-47$, all values mean \pm 1 standard error.

\begin{tabular}{cccc}
\hline & $a$ & $b$ & $c$ \\
\hline BRF & $-2.48 \pm 0.56 \mathrm{~B}$ & $0.094 \pm 0.009 \mathrm{~A}$ & $-0.00034 \pm 0.0001 \mathrm{~A}$ \\
Upper Canopy & $-2.166 \pm 0.105 \mathrm{a}$ & $0.084 \pm 0.006 \mathbf{a}$ & $-0.00014 \pm 0.0001 \mathrm{a}$ \\
Lower Canopy & $-2.829 \pm 0.371 \mathrm{~b}$ & $0.104 \pm 0.017 \mathrm{a}$ & $-0.00053 \pm 0.0003 \mathrm{a}$ \\
\hline FTE & $-1.15 \pm 0.09 \mathrm{~A}$ & $0.086 \pm 0.003 \mathrm{~A}$ & $-0.00027 \pm 0.0001 \mathrm{~A}$ \\
\hline Upper Canopy & $-1.20 \pm 0.29 \mathrm{a}$ & $0.087 \pm 0.004 \mathrm{a}$ & $-0.00028 \pm 0.0001 \mathrm{a}$ \\
Lower Canopy & $-1.10 \pm 0.27 \mathbf{a}$ & $0.084 \pm 0.005 \mathrm{a}$ & $-0.00026 \pm 0.0003 \mathrm{a}$ \\
\hline All Trees & $1.82 \pm 0.12$ & $0.090 \pm 0.003$ & $-0.00030 \pm 0.0001$ \\
\hline
\end{tabular}




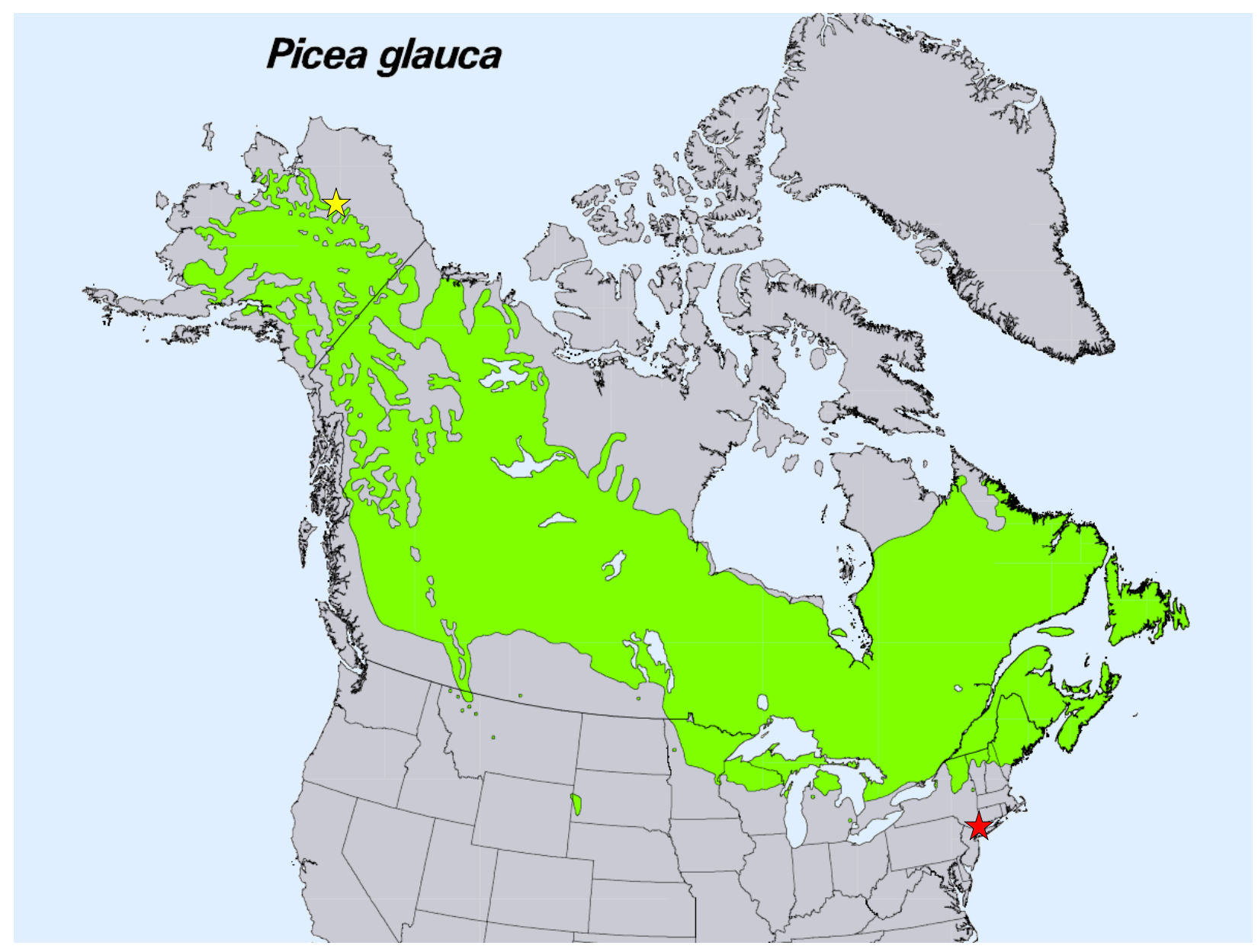

739 Figure 1. Species range distribution for Picea glauca. The southern range limit site, Black Rock Forest, Cornwall NY, is marked with the red star. The arctic treeline site in northern Alaska is marked with a yellow star. Map from U.S. Geological Survey, Department of the Interior/USGS based on original data from Little (1999). 

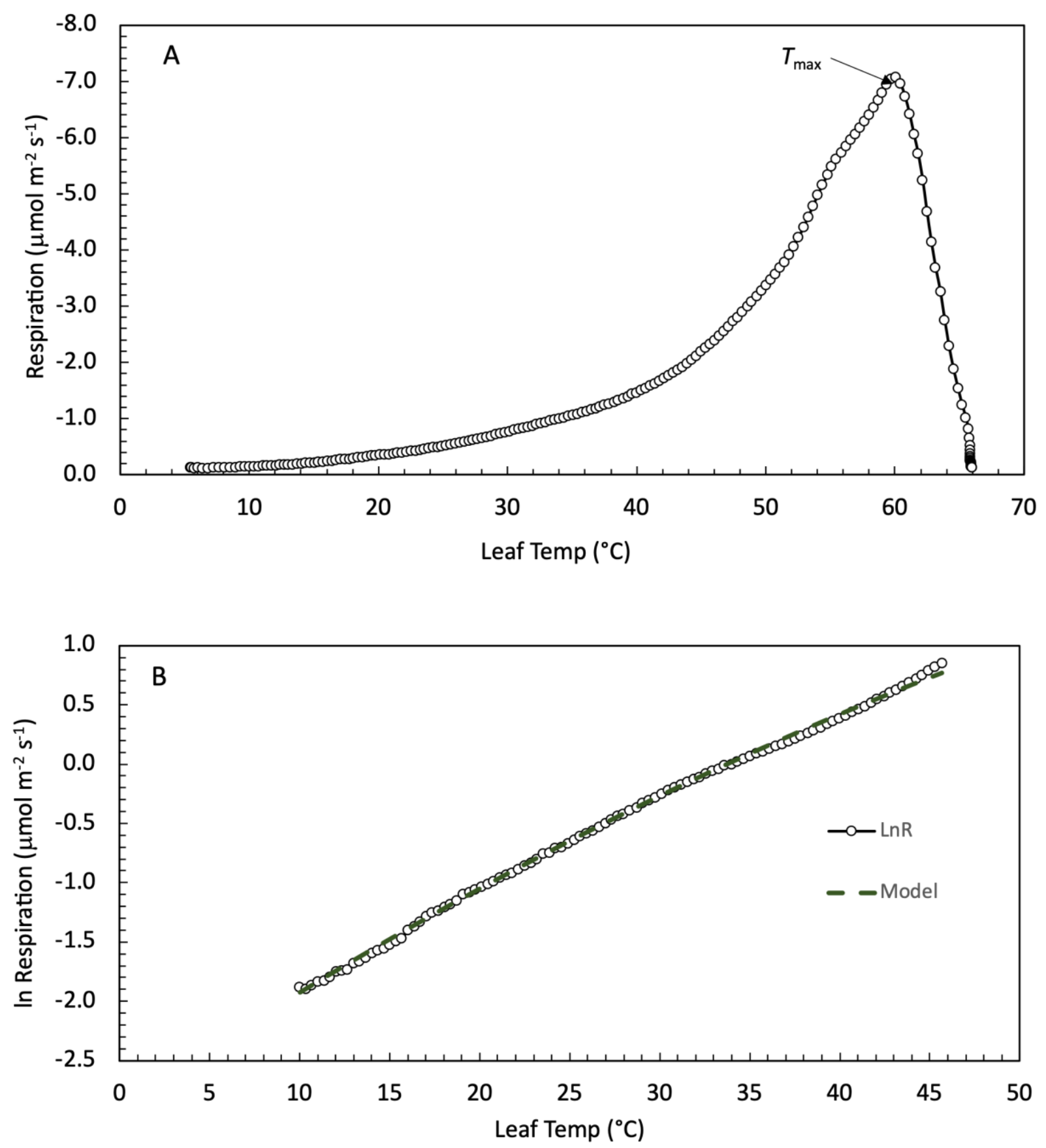

745 Figure 2. Leaf respiration as a function of temperature in Picea glauca measured at the southern 746 end of the species distribution in Black Rock Forest, Cornwall, NY USA. Panel A (top) is an example high-resolution temperature response curve measured from 5 to $65^{\circ} \mathrm{C}$. Air temperature was heated at a rate of $1^{\circ} \mathrm{C} \mathrm{min}^{-1}$ while the rate of $\mathrm{CO}_{2}$ release and other gas-exchange parameters were recorded every 20 seconds. Panel B (bottom) is the log of measured respiration rate and model fit $\left(\ln R=a+b T+c T^{2}\right.$ - see text for full description) between 10 and $45^{\circ} \mathrm{C}$ for the same 751 sample. 


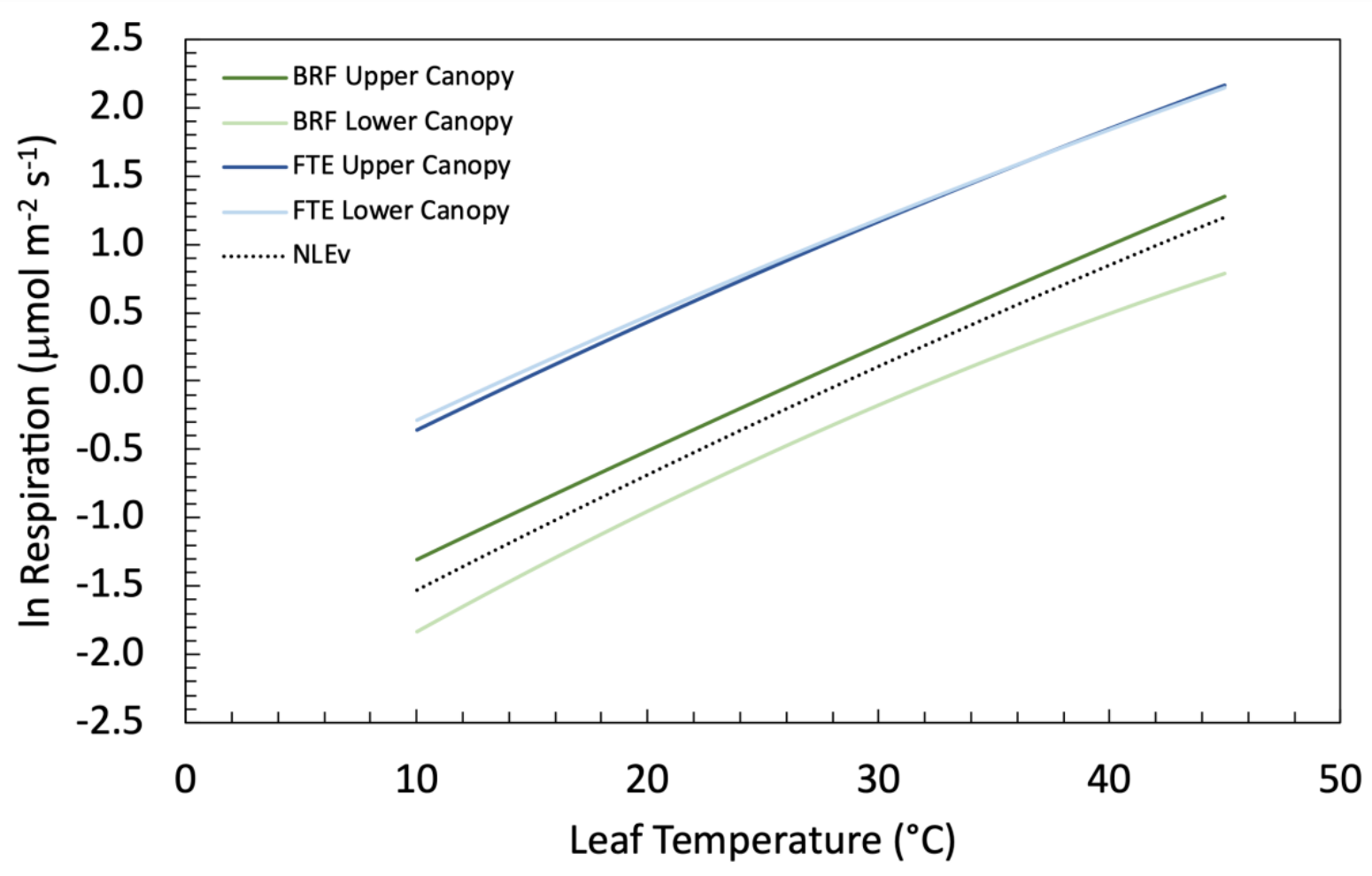

753 Figure 3. Average model results (log of leaf respiration) for the bottom of canopy (light green and blue lines) and top of the canopy (dark green and blue lines), of Picea glauca trees growing at either the south-eastern edge of the species range (green lines) in Black Rock Forest, NY USA, or the northern edge of the species range limit (blue lines) in the Forest Tundra Ecotone (FTE) in northcentral AK, USA. Line presents the mean response ( $\mathrm{n}=6$ (BRF) or 18(FTE) and shaded area $=95 \%$ confidence interval for each canopy position. Also shown is the average response for Needle-Leaved Evergreen species (NLEv) from the global survey of Heskel et al (2016) (black dotted line). Model parameters are presented in table 2. 


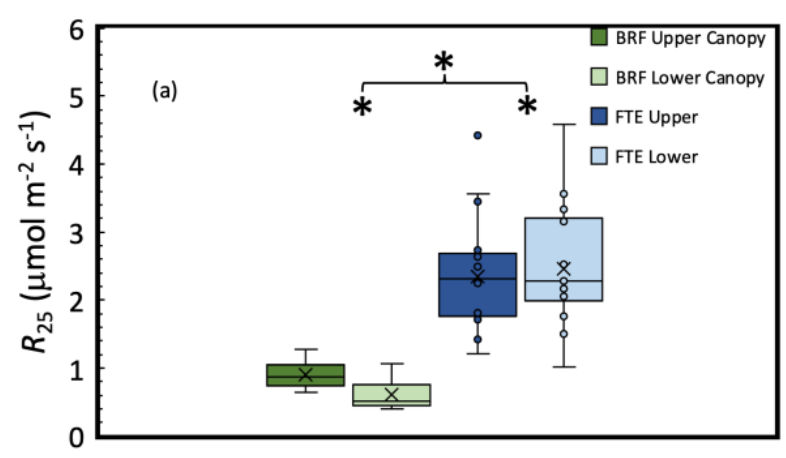

763 Figure 4. Respiration of White Spruce (Picea glauca) foliage measured from the upper (dark
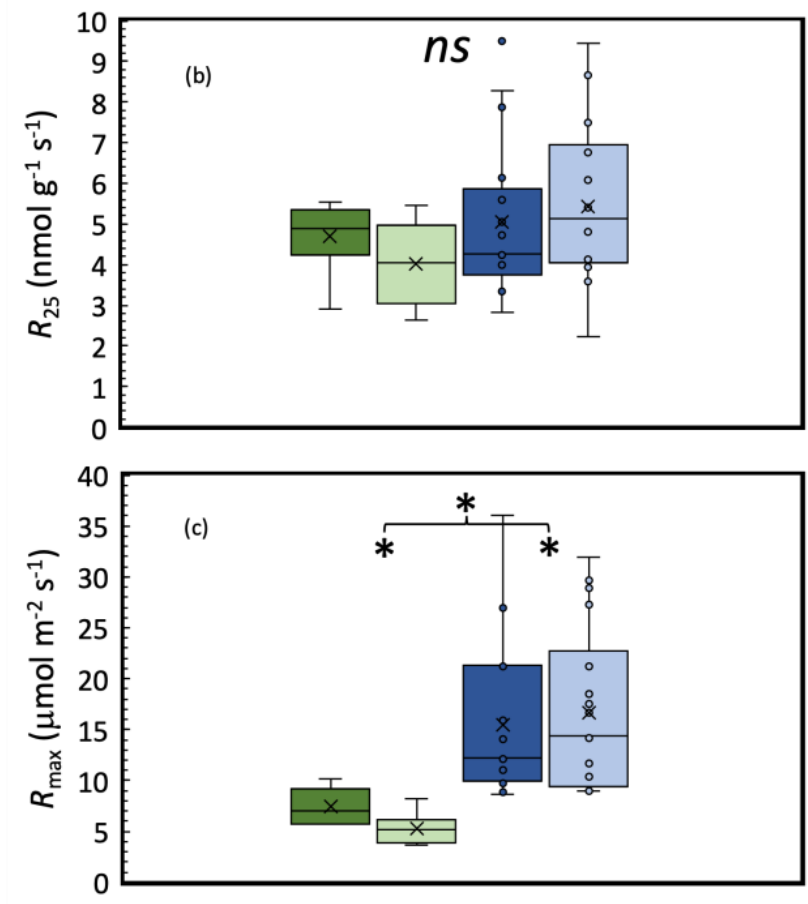
the upper (dark blue) or lower (light blue) canopy from the northern location (Forest Tundra Ecotone, AK USA). Respiration was measured at a leaf temperature of $25^{\circ} \mathrm{C}$ either on a projected leaf area basis (panel a, top), leaf mass basis (panel b, center) as well as the maximum rate of respiration from a temperature response curve, expressed on a leaf area basis (panel c, bottom). The middle line of the box represents the median, the x represents the mean. The box is drawn between the first and third quartiles and the whiskers extend to the minimum and maximum values. $*=$ statistical significance $(\mathrm{p}<0.05$, panels a and $\mathrm{c}) . n s=$ not significant (panel 


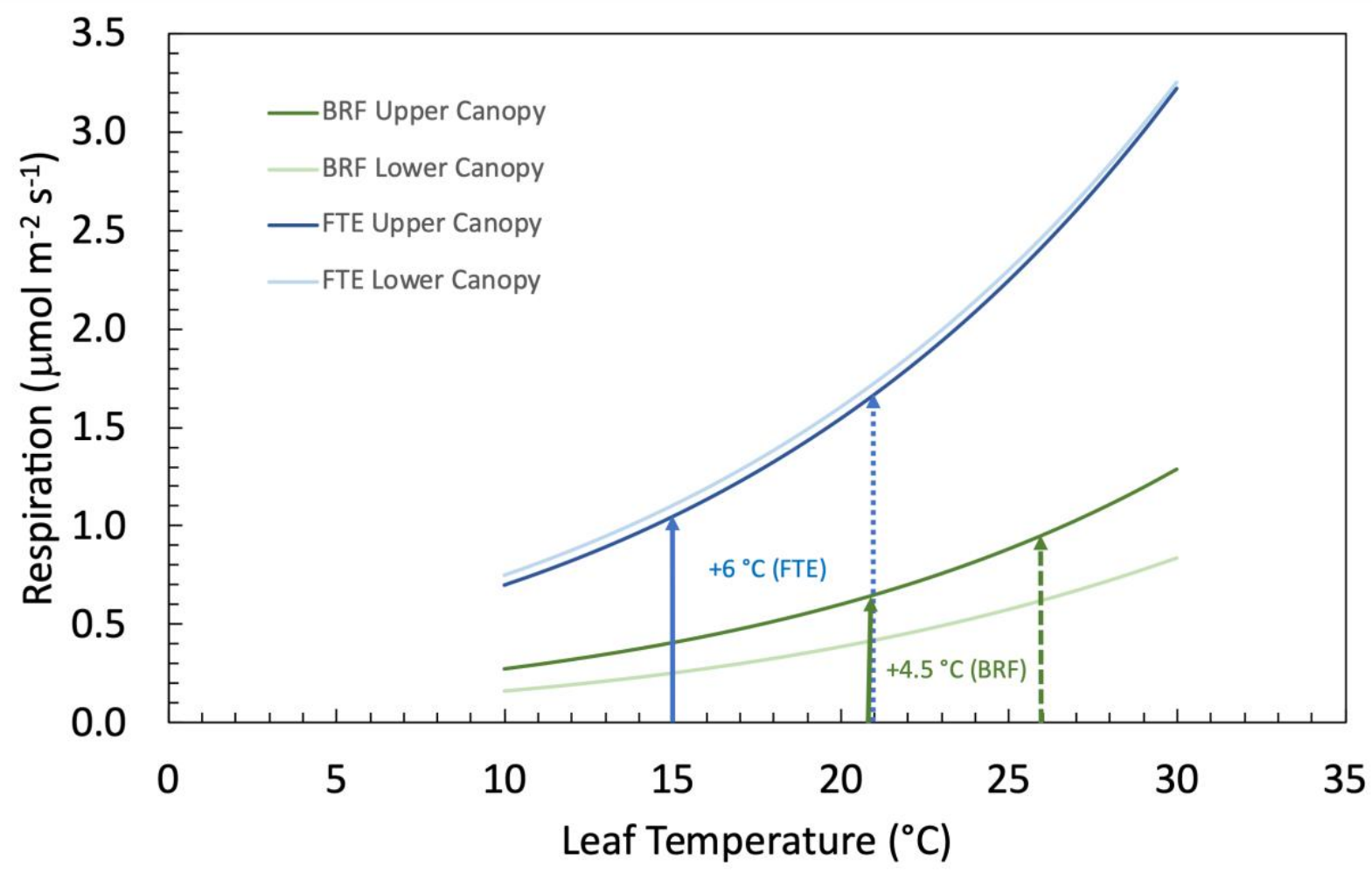

776 Figure 5. Modeled rates of White Spruce (Picea glauca) foliage respiration vs. leaf temperature from two canopy positions at either the northern or southern range limits of the species. Lines display the average modeled response from the upper (dark green) or lower (light green) canopy from the southern location (Black Rock Forest, NY USA, n=6), and the upper (dark blue) or lower (light blue) canopy from the northern location (Forest Tundra Ecotone, AK USA, n = 18). Vertical arrows represent the average June, July, August temperatures from each of the field sites ( solid blue $=\mathrm{FTE}$, solid green $=\mathrm{BRF})$ and the projected end of century increases (dashed blue $=$ FTE projection, dashed green $=$ BRF projections, see text for more information). 